\title{
THE EFFECTS OF THE CUSTOMS UNION ON TURKISH HOME APPLIANCE INDUSTRY*
}

\section{Zelha ALTINKAYA}

\section{Abstract:}

The aim of this study is to evaluate the impact of the Customs Union on Home Appliance Manufacturing Industry in Turkey in the period between 1996-2006. The home appliance industry has been producing domectically since 1960s. Most of the product in the industry has been produced only by one or two producers for a long time. Only after 2000, the number of producers who produce refrigerator inreased to three. Not only the number of producers but previous studies on the concentration ratios also support that the structure of the home appliance industry is oligopolistic market structure. In 1996, the tariffs for the home appliance products imported from the European Union were reduced to zero. This raised the volume of import from the European Union Countries. The net profit margin for the leading company in Turkey was $10 \%$ in 1996 where the same ratio is $2.1 \%$ for Whirlpool, a leading multinational company. While in the 15 years period, Whirlpool have kept its profit level around the same ratios during the period from 1991 to 2006 , the ratio decreased $4.7 \%$ for the leading company in Turkey, in 2006. This decrease would be explained by large increase in the volume of the import of these products when the tariffs were removed in 1996.

Keywords: The Customs Union, home appliance industry, oligopoly, import discipline hypothesis

\section{Özet:}

Bu çalışma, Gümrük Birliği'ninö 1996-2006 yılları Beyaz Eşya Sanayi üzerindeki etkisini değerlendirmeyi amaçlamaktadır. Beyaz Eşya Sanayi yurtiçinde üretime $1950^{\prime}$ lí yıllardan itibaren başlanmıştır. Ürünlerin pek çoğu sadece bir yada iki üretici tarafindan üretilmiştir. Ancak, 2000 yılından

\footnotetext{
* This article is a reformulation and summary of the author's Ph. D thesis submitted to the European Union Institute of Marmara University.
} 
sonra endüstrideki üretici sayısı üçe çıabilmiştir. Beyaz eşya sanayinde daha önceki yıllarda yapılan çalışmalar da endüstri de yoğunlaşmanın yoğun olduğunu göstermektedir. 1996 yılında Gümrük Birliği'nin başlamasıyla, Avrupa Birliği'nden ithal edilen beyaz eşya ürünlerinden alınan gümrük vergi ve tarifeleri sıfırlanmıștır. Bu nedenle, Avrupa Birliği'nden ithal edilen beyaz eşya ürünleri hacmi genişlemiştir. Hem üretici sayısının artması, hem de yapılan ithalatın artması, beyaz eşya pazarındaki rekabeti artırmıştır. Levinshon'un en önemli argümanı olan, ithalat disipline eder yaklaşımı, Türkiye beyaz eşya sanayinde de etkin olmuş, artan rekabet ile birlikte rekabet artmış ve 1990 lı yıllarda çok aşırı karlar elde edilen beyaz eşya sanayinde, $2000^{\prime} l i$ yılların ortalarında, karlılık oranında bir düşüş önemli bir düşüş kaydedilmiştir. Sektörde lider konumda olan firmanın "net karlılığı" $1996 \% 10$ iken 2006 yılında \%4. 7 düşmüştür.

Anahtar kelimeler: Gümrük Birliği, beyaz eşya sanayi, oligopoly, ithalat disipline eder

\section{1- Introduction}

The aim of this study is to evaluate the impact of the Customs Union on Home Appliance Manufacturing Industry in Turkey. The basic idea behind the Customs Union is to utilise the benefits of free trade amonlooojkrfdsazx. $1 \mathrm{~kg}$ the trading parties. Although, this is the basic argument of traditional trade theory on perfectly competitive market, the latest developments in international trade required inclusion of imperfectly competitive markets into theory. Depending on the challenges in theories, the policy arguments have also been changed. Especially, development in industrial economics and the arguments for the structure conduct performance paradigm and game theory put forward the policies which can also be effective in international trade. The selective use of trade barriers and industry subsibidies in order to capture the profits handled by foreign firms is only one of these policies. The effective trade and industry policies, especially import policies would discipline the markets which are highly concentrated. In these markets, import disciplines the extraordinary profits of the firms. In this study, the effect of the Customs Union on home appliance industry will be analysed. Turkish home appliance sector was composed of two sub groups: white home appliance sector and brown home appliance sector. Recently, this classification of the home appliance sector were removed and both type of products have been called consumer durables or home appliance industry. 


\section{2- Previous Studies On The Effect of the Customs Union on Turkish Economy}

Before this study, there were many studies evaluating the implication of liberalization policies in Turkey since 1980. After Krueger and Tuncer, Foroutan was the second who analysed the process, Foroutan pointed out that import penetration in the highly concentrated private sectors reduced the gross pofit margin in Turkey within the period 1977-1985. Similarly, Katırcıoglu, Engin and Akçay and Yalçın were the others who tested the price-cost margins by using least square estimation method on panel data of Turkish manufacturing industries over 1983-1994. Katırcioglu, Engin and Akçay found out the import penetration due to foreign trade liberalization of the 1980 s reduced the concentration on many oligopolistic industries.

Recently, Akgündüz (2005) estimated income and price elasticities of import demand of 9 EU countries by analyzing the period between 1987 and 2004. This paper put forward that the price variable in the long-run import demand function of Turkey from Germany, Belgium and Denmark had negative sign unexpectedly. The real exchange rate does not affect import demand in the long-run from UK, Italy, Portugal and Denmark. This was surprising result either (Akgündüz, 2005).

Seymen and Utkulu (2006) analysed the level of price competitiveness of the Turkish firms in the EU Single market in aggregate level for the period 1963-2002. They concluded that both the long-run price and income elasticities of Turkish Exports to the EU significantly reduced after the Single Market. Although the income elasticity was significant and high, measure of import capacity lowered the price elasticity (Seymen and Utkulu, 2006: 38)

Neyaptı and Taşkın and Üngör( 2004) estimated import and export functions of Turkey with the EU and non-EU countries. They observed that the income elasticity of both imports and exports are lower for the EU countries, especially for the CU period. While the effect of real exchange rate on export was stronger for the period of the CU. This was explained by the increased imports for during the periods of largely overvalued TL, especially for the period 1993-2000 (Neyaptı and Taşkın and Üngör, 2004).

Özkale and Karaman (2006) focused on general demand function and main trade commodity groups. They found out that the price changes did not effect the aggregated import demand function. Özkale and Karaman investigated the differences with regards to volume and behavioural aspects for $19 \mathrm{EU}$ countries and 16 non-EU countries (Özkale and Karaman, 2006). Real import demand was considered as a function of domestic income and 
real exchange rate. Özkale and Karaman selected 2004 as the base year and first 10 importing chapters $(85$ chapter of these importing chapters is electrical machinery and including home appliances products). According to the estimation results of equations, after the $\mathrm{CU}$ imports from the non-EU countries decreased. They repeated the analysis using equations and found that the CU did not have not trade creation ${ }^{1}$ and trade diversion effect. Özkale and Karaman interpreted that in case of a decrease in Turkey's GDP, she would give up imports from non-EU countries while imports from the EU countries became less responsive to price changes and imports from non-EU countries became more responsive. Import demand of electrical goods and machinery from the EU increased after the $\mathrm{CU}$, the agreement made trade creative effect (Özkale and Karaman; 2006: 16)

In their analysis, Erzan, Filiztekin and Zenginobuz (2007) tested the relationship between industry structure and trade variables. When industries were treated together without grouping them according to $\mathrm{CR} 4^{2}$, it was observed that increases in output concentration significantly loaded import penetration. When concentration is reduced in concentrated industries through new domestic entry, the share of imports in total consumption would increase. The evaluation of the test results on the impact of industry structure was challenging: concentration reduced exports significantly. Erzan, Filiztekin and Zenginobuz also observed that the impact of PriceCost Margin (PCM) on import penetration was qualitatively same as the impact of CR4 on import penetration. When the study was considered from the import discipline hypothesis perspective, it was observed import penetration does not have any effect on market concentration. When industries were grouped according to their concentration levels, import

\footnotetext{
1 Trade creation effect: Trade creation means that a free trade area creates trade that would not have existed otherwise. As a result, supply occurs from a more efficiency producer of the product. In all cases trade creation will raise country's national welfare.

Trade diversion effect: $\mathbf{A}$ free trade area diverts trade away from a more efficient supplier outside the FTA, towards a less efficient supplier within the FTA. In some cases, trade diversion will reduce a country's national welfare but in some cases national welfare could improve despite the trade diversion.

${ }^{2}$ Herfhindall Index calculated by summing the square of all firm's market share. It takes value from 0 to 1 . If it is calculated to close to 0 , then there is low level concentration. If it is calculated as close to 1 , there can be more level of concentration ratios. CR 4 is calculated for the first four leading firms in the sector while the CR8 shows the concentration ratio for the eight leading firms.

0 -30 indicates low level of concentration

31-50 indicates medium level of concentration

71-100 indicates high level of concentration.
} 
penetration did not reduce concentration in concentrated industries, while for less concentrated industries changes in import penetration had not significant negative impact on market concentration. As for export, no significant impact of exchanges in exports on industry structure was observed for either low or high concentration industries.

Saatçi and Aslan (2007) also analysed disciplinary effects of import on Turkish manufacturing industry with two digits under the period starting from 1966 to 2001. Saatçi and Aslan used the panel data in this analysis. Since until that time, the most of the studies were covering different short term periods, they produced different results. Some of them were supporting the import discipline hypothesis and some of them were not. So, Saatçi and Aslan studied so long period of time for the first time on Turkish manufacturing industry. The study concluded that the relationship between import and Turkish manufacturing industry is positive and statistically siginificant. This conclusion approved that the import liberalization just decreased the profitability on Turkish manufacturing industry. Whenever Saatçi and Aslan focused on the relationship between export and price and cost, they also found negative and statistically significant relationship among them. Saatçi and Aslan explained this by stating that whenever the producers producing in the imperfectly competitive markets export to foreign countries, they would not discriminate the prices on domestic market and foreign markets and the increase in export inversely effected the price-cost margin on products like it is the case in import discipline hypothesis. They also conclude that the relationship between capital and price-cost margin has been negative and statistically insignificant which means increase in the volume of capital decrease the profitability of production in the analysis period ( Saatçi and Aslan, 2007;1-15).

\section{3- The Structure of Turkish Home Appliance Industry}

It is claimed that foreign trade liberalization increases the welfare of a country further under the imperfectly competitive domestic markets because it reduces distortions created in the imperfect competitive markets by removing of barriers. If there are a few domestic firms in a domestic market, the removal of barriers on international trade allow firms acting in industries to enjoy profits in a protected domestic market and force these firms to behave competitively. The effects of removal of tariffs or other trade restrictions are more active in the competitive markets. Levinsohn (1993) calls this situation as "imports as market discipline hypothesis" and defines this hypothesis as the hypothesis about how firms respond to a change in trade policy. Levinsohn's hypothesis can be defined as derivation of the 
"Structure-Conduct-Performance" paradigm. Here, firstly, then the structure of the industry will be analysed, then trade effects would be analysed

While within the argument of structure -conduct-performance paradigm, it is argued that structure of the markets determines the conduct of the firms in the market, the conduct of the firms also determines the performance of the firms. Mostly, in competitive structure, firms get normal profits, industries with economies of scale and market power get higher profits than the normal. While trade liberalization would remove trade barriers and make markets more competitive, changes in the market structure from concentrated markets to competitive markets would also change the conduct of the companies, companies would start to behave more competitively and reduce prices and the extraordinary profits.

Abraham Lincoln summarizes his idea on foreign trade as follows: "when I buy coat from England. I have to coat and England has the money. But when I buy a coat in America, I have the coat and America has the money" (Dixit, 1986: 288). This argument states an important general principle for determining policy and its relevancy to social desirability and opportunity $\operatorname{cost}^{3}$.

In mercantilist view, in perfectly competitive markets, free entry means no excess profit exists in the market. Thus, Americans could not benefit from supplying Lincoln's coat and since producing just one extra coat may be matter of indifference as long as the price of coat equals to marginal cost of producing an extra coat to the society as a whole at the margin. Therefore, Dixit does not evaluate this as mercantilist policy to encourage purchase of American coats to discourage to purchase of English coat (Dixit, 1986: 289). When the numbers of coats produced increase and diminishing returns might arise the cost of production above the price, this would be a loss making proposition for the American society as a whole. The losses could be compensated where the coat prices reduce all over the world. Under these conditions, an anti-mercantilist policy of export restraint would be required. In new mercantilist view, the basic model of the economy change to cover the imperfect competition. Firms operating behind the barriers would keep prices in excess of pure profits. Since, these can be thought of as scarcity values of the restricted positions in the industry, this is called as monopoly rent.

${ }^{3}$ Opportunity cost: The cost of an input is the value of the forgone opportunity to put it to the next best available use. If markets are functioning efficiently, the prices of inputs will equal their opportunity costs 
Any project which substantial amount of capital has been sunk into research and development and only one or a few firms succeed and go on the production stage and these gets large monopoly profits. They would not have undertaken the investment without the prospect of such a reward. After successful firms have become organized in the industry, the sunk cost will constitute an entry barrier for new firms. There is usually free entry to the whole process. In the case where firm plans to make investment into R\&D during the early stage of the industry's evaluation, there would be zero excess profit for the process as a whole, the profits of successful firms would just match the losses of the rest (Dixit, 1986: 292). So, if the firms continue to have excess rents, the concentration ratio is a well organized measure of imperfectly competitive markets. Home appliance industry with its structures which require high initial cost and high $R \& D$ programs is the typical example of imperfectly competitive market. Even all over the world, the number of producers in the home appliance industry is so low that naturally the home appliance industry in each country has imperfectly competitive market structure. In Turkey, it is the same, home appliance industry has been one of the highly concentrated industries. In addition to the imperfectly competitive market structure, the high tariffs rates imposed on the import of home appliance industry, the industry was one of protected industry.

The Turkish home appliances sector started to production as an assembly industry in the 1950's. The first Turkish made refrigerator was introduced to the market in 1960. It was produced by "Arçelik". The seventies were the first years that Turkey produced the other domestic home appliance products under its own trade mark again by Arçelik. Although demand for home appliance products was considerable, the production capacity was limited. This could be due to the technical difficulty. The large part of the domestic consumption was provided by domestic production. Especially, at the beginning of the 1970's, it is observed there was not import from the foreign countries, although, there were small amount of export. The home appliance industry was protected by serious amount of tariffs. In 1971, the average amount of production was 200.000 units annually (IGEME, 1973: 7). At that time, there were nine producers (including suppliers od auxiliary products) in refrigerator industry. However, only five of them were effective producers and 54 per cent of total production were carried only by one firm. The 31 per cent of remaining part was also produced by the second firm in the industry. So, the 85 per cent of the total supply was provided by only two firms. Following table shows the detail of production capacity of leading firms in $1970 \mathrm{~s}$. 
Table 3. 1: Refrigerator Production Capacity in Turkey in 1970s

\begin{tabular}{|l|r|r|r|r|}
\hline Firm & \multicolumn{2}{|c|}{ Annual Capacity } & \multicolumn{2}{c|}{ Current Production } \\
\hline & $\mathbf{1 9 7 0}$ & $\mathbf{1 9 7 1}$ & $\mathbf{1 9 7 0}$ & $\mathbf{1 9 7 1}$ \\
\hline A & 70.000 & 108.000 & 106.210 & 116.056 \\
\hline B & 45.000 & 45.000 & 52.210 & 66.839 \\
\hline C & 24.780 & 25.000 & 13.725 & 19.838 \\
\hline D & 12.500 & 12.500 & 5.489 & 10.617 \\
\hline E & 7.000 & 7.000 & 800 & 857 \\
\hline Total & $\mathbf{1 5 9 . 8 0 0}$ & $\mathbf{1 9 7 . 5 0 0}$ & $\mathbf{1 7 8 . 4 2 5}$ & $\mathbf{2 1 4 . 2 0 7}$ \\
\hline
\end{tabular}

Source: İGEME, 1973 (Türkiye Cumhuriyeti Sanayi Bakanlığı ve Istanbul Sanayi Odası (Ministry of Industry of the Republic of Turkey and Istanbul Chamber of Industry)

The average amount of production per firm and total production by industry was limited. Therefore, they were able to charge very high prices to their product since they were operating in imperfectly competitive markets. The small scale firms also determined their price at a high level since they were protected by high customs duties, although, they were unable to increase their production level because of financial difficulties and improper production techniques. The profit cost margin of these firms were $30 \mathrm{per}$ cent. Other firms which were producing in modern technology, management and organizations would produce at a lower cost and apply high prices.

In 1980s, although there were five producers producing refrigerator, ninety per cent of products were produced by Arçelik and Profilo

Table 3. 2: Production Capacity in Home Appliance Products in Turkey

\begin{tabular}{|c|c|c|c|c|c|c|c|c|c|c|c|c|}
\hline & \multicolumn{3}{|c|}{ Refrigerator } & \multicolumn{3}{|c|}{ Washing Machime } & \multicolumn{3}{|c|}{ Disk Washer } & \multicolumn{3}{|c|}{ Vacuum Cleaner } \\
\hline $\begin{array}{l}\text { Years } \rightarrow \\
\text { Firm }\end{array}$ & 1985 & 2000 & 2005 & 1985 & 2000 & 2005 & 1985 & 2000 & 2005 & 1985 & 2000 & 2005 \\
\hline Arçelik & 600 & 1400 & 3200 & & 1150 & 3100 & 0 & 500 & 900 & N.A & $10 \overline{0}$ & $100 \overline{0}$ \\
\hline Profilo (1) & 690 & 800 & 1550 & & $45 \overline{0}$ & 450 & $\overline{0}$ & 0 & 0 & N.A & 0 & 0 \\
\hline Vestel & 0 & 700 & 2750 & 0 & 0 & 2500 & 0 & 0 & 0 & N.A & 0 & 0 \\
\hline Presiz & 100 & 0 & 0 & 0 & 0 & 0 & 0 & 0 & 0 & N.A & 0 & 0 \\
\hline Others & 26 & & & & & & & & & & & \\
\hline Total & 1416 & 2900 & 7500 & 0 & 1600 & 6050 & 0 & 500 & $\overline{900}$ & N.A & $10 \overline{0}$ & $100 \overline{0}$ \\
\hline
\end{tabular}

(1) BSH Profilo

Source: Dayanıkı Tüketim Malları İhracat Pazar Araştırması, Durable Consumption Goods Export Markets Research, Türkiye İhracatı Geliştirme Merkezi, Export Promotion Center of Turkey, 1985;

Annual Reports 1999, 2000, 2001, 2002, 2003, 2004, 2005. http: www. arçelik. com. tr; www. bshp. com. tr, 2002; www. bsh. com. tr, www. vestel. com. tr. 
Profilo Inc. had the highest capacity in refrigerator production in 1985. It was dominating 48 per cent of the whole market. Annual production capacity increased to 1. 416. 000 units per year. By trade liberalization program of 1980 , home appliance sector also started to export leading growth. Although, since 1989, the industry faced more competition by reduction the customs duties for the home appliance goods imported from the EU, it continued to grow, even in foreign markets. Therefore, this growth can be interpreted as the result of growing competition that caused improvement of quality standards in production, $R \& D$ investments and formulation of marketing and production strategies.

By the year 2000s, in Turkish Home Appliance sector, all products of home appliance industry refrigerator, washing machine, dish washers, cooking appliances, vacuum cleaners, television were produced. After, the third largest firm, Vestel, invested for a large amount of production capacity in 2003 , the total production capacity for refrigerator increased to 3. 300 . 000 units per year. There were eight major producers, more than 50 medium scale manufacturing firms in the industry. Eight major producers are the members of the Türkiye Beyaz Eşya Sanayicileri Derneği (TÜRKBESD), (White Goods Industrialist Association of Turkey (TWGIA)).

Table. 3. 3: Production and Domestic Sales in Turkey"s Home Appliance industry / 1000 Units

\begin{tabular}{|c|c|c|c|c|c|c|c|c|}
\hline \multirow[t]{2}{*}{ Years } & \multicolumn{2}{|c|}{$\begin{array}{c}\text { Refrigerator } \\
\text { (1) }\end{array}$} & \multicolumn{2}{|c|}{$\begin{array}{l}\text { Washing Machime } \\
\text { (1) }\end{array}$} & \multicolumn{2}{|c|}{$\begin{array}{c}\text { Dish Washer } \\
\text { (1) }\end{array}$} & \multicolumn{2}{|c|}{$\begin{array}{c}\text { Vacuim Cleaner } \\
\text { (2) }\end{array}$} \\
\hline & Production & $\begin{array}{l}\text { Domestic } \\
\text { Sales }\end{array}$ & Production & $\begin{array}{c}\text { Domestic } \\
\text { Sales }\end{array}$ & Production & $\begin{array}{l}\text { Domestic } \\
\text { Sales }\end{array}$ & Production & $\begin{array}{l}\text { Domestic } \\
\text { Sales }\end{array}$ \\
\hline 1990 & 960 & 913 & 758 & 734 & 63 & 85 & 261 & $\overline{244}$ \\
\hline 1995 & 1637 & 940 & 828 & 786 & 236 & 241 & 879 & 394 \\
\hline 1996 & 1638 & 1129 & 993 & 1067 & 255 & 319 & 1055 & 508 \\
\hline 1997 & 1849 & 1303 & 1454 & 1464 & 447 & $4 \overline{27}$ & 1297 & 725 \\
\hline 1998 & 1875 & 1711 & 1375 & 1494 & 318 & 478 & 1172 & 810 \\
\hline 1999 & 2139 & 1610 & 1219 & 1222 & 325 & 406 & 1066 & 743 \\
\hline 2000 & 2446 & 1244 & 1343 & 1121 & 351 & 278 & $11 \overline{73}$ & $86 \overline{6}$ \\
\hline 2001 & 2483 & $1 2 \longdiv { 5 5 }$ & 1029 & 614 & 223 & $15 \overline{8}$ & 591 & 762 \\
\hline 2002 & 3318 & 1424 & 1684 & 721 & 346 & $\overline{195}$ & 785 & $82 \overline{9}$ \\
\hline 2003 & 4286 & 1680 & 2459 & 949 & 399 & $15 \overline{6}$ & 768 & 893 \\
\hline 2004 & 5308 & 2486 & 3963 & 1686 & 657 & 385 & 1563 & 1602 \\
\hline 2005 & 5538 & 2140 & 4382 & 1675 & 783 & 412 & 1206 & 1289 \\
\hline
\end{tabular}

Source: BEYSAD- WGSA Statistics, 2006: http: //www. beysad. org. tr /statistics

(1) for the data from 1990 to 2002 TÜRKBESD, for the data from 2002-2003 Yüzal, 2005 www. igeme. gov. tr, for the data from 2003-2005 Esen 2007 www. igeme. gov, tr

(2) TÜIK, Üretim İstatistikleri Yıllıkları, Production Statistics, Yearly Data Base www. tuik. gov. tr 
Depending on the population, income and technology, the increase in demand of refrigerator also increased the production capacity. The total production capacity reached to 3.6 million units in 2000 and 7.5 million in 2005. Six firms were producing refrigerator during 2000s. Arçelik, BoschSiemens-Profilo, Vestel Beyaz Eşya and Merloni Elettrodomestic. In Turkey, the total production capacity for refrigerator of leading three home appliance producers became 7. 5 million units by the year 2005 (Yüzal, 2006: 1). During the 40 years period, Arçelik has maintained its leadership in Turkish home appliance sector. Arçelik became one of the fifth largest home appliances manufacturers in Europe with its significant investments and marketing and sales policies. Turkey.

A positive macroeconomic environment, low inflation rate, low consumer credit interest rates and delayed demand during the economic crisis, in the year 2003 and 2006, the considerable growth in home appliance goods was observed in Turkey. These indicators also encouraged production capacity increasing investments. Rapid growth in construction sector also pushed the growth in housing establishments. So. The total production for refrigerators were for 6.7 million units, for washing machine 5. 2 million units and dishwashers for 1.2 million units in 2006.36 per cent of the total production was sold in domestic market, and the remaining part, 64 per cent was exported to over 100 countries. While refrigerators production had the highest output units, dishwasher production had 52. 2 per cent increases due to the low market diffusion in Turkey (Annual Report of Bosch-Siemens-Profilo, 2007). With further capital investment the sector grew its production capacity, and factor output of large domestic appliances was up 6 per cent for the year. During the analysis period, rapid development in technology deeply changed the product models, while in 1970 , the refrigerator with double doors may be considered as luxury product, nowadays, refrigerators with energy saving specification are the new models; or washing machine with 15 minutes wash-cycles, dishwashers with anti-fingerprint were considered as luxury models(Annual Report of Arcelik, 2006). The high-technology used in production process, high priority in R\&D activities have been the main features of Turkish home appliance industry. 
Graph: 3. 1

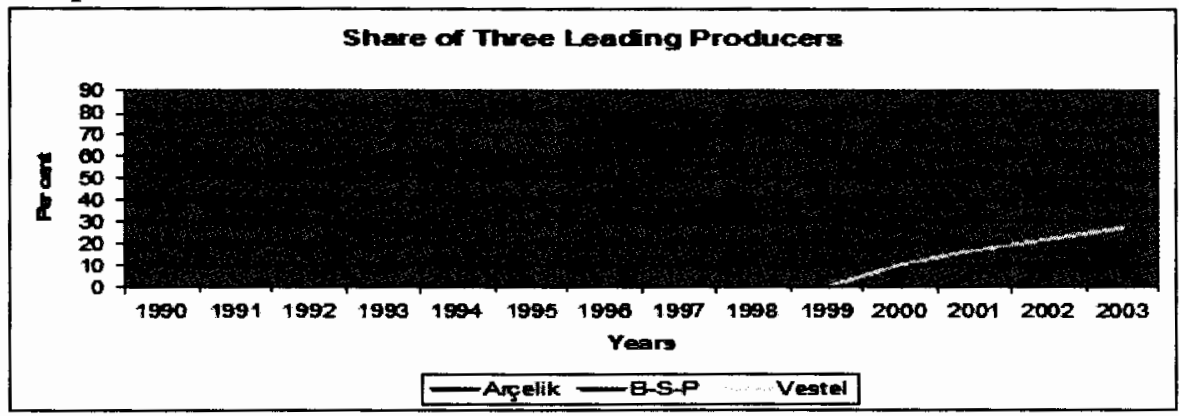

Source: This graph is arranged by the data given on the table 3.4

Table 3. 4. : Refrigerator Production of Producer Companies in Turkey/1000 Units

\begin{tabular}{|r|r|r|r|r|r|r|r|}
\hline Years & $\begin{array}{c}\text { Arçelik } \\
(1)\end{array}$ & $\begin{array}{c}\text { Share of } \\
\text { Arçelik } \\
(2)\end{array}$ & $\begin{array}{c}\text { Bosch } \\
\text { Siemens } \\
\text { Profilo } \\
(3)\end{array}$ & $\begin{array}{c}\text { Share of } \\
\text { B-S-P } \\
\%(2)\end{array}$ & $\begin{array}{c}\text { Vestel } \\
(4)\end{array}$ & $\begin{array}{c}\text { Share of } \\
\text { Vestel \% } \\
(2)\end{array}$ & $\begin{array}{c}\text { Total } \\
\text { Production }\end{array}$ \\
\hline 1990 & 537 & 56 & 416 & 43 & 0 & 0 & 965 \\
\hline 1995 & 901 & 55 & N. A. & & 0 & 0 & 1637 \\
\hline 1996 & 984 & 60 & 524 & 32 & 0 & 0 & 1638 \\
\hline 1997 & 1140 & 62 & 601 & 33 & 0 & 0 & 1849 \\
\hline 1998 & 1454 & 78 & 598 & 32 & 0 & 0 & 1875 \\
\hline 1999 & 1375 & 64 & 656 & 31 & 0 & 0 & 2139 \\
\hline 2000 & 1219 & 50 & 654 & 27 & 235 & 10 & 2446 \\
\hline 2001 & 1343 & 54 & 460 & 19 & 429 & 17 & 2483 \\
\hline 2002 & 1500 & 45 & 520 & 16 & 723 & 22 & 3318 \\
\hline 2003 & 1900 & 44 & 672 & 16 & 1139 & 27 & 4286 \\
\hline 2004 & N. A & N. A & 903 & 17 & 1415 & 27 & 5308 \\
\hline 2005 & N. A & N. A & 1.029 & 19 & 1718 & 31 & 5538 \\
\hline
\end{tabular}

Source: IMKB, (Istanbul Stock Exchange), Financial Reports of The Companies

(1), (3) are taken from Year Book of the Companies Stated in IMKB, http://www. imkb. gov. tr /bilanco/mtablodonem. htm; (1)Annual Reports of Arcelik, http: //www. arcelik. com. tr/ Yatirimcilliskileri/ImkbArcelik/?MENUID=2; Annual Reports of BSP http: //www. profile. com. tr; http: //www. bosch. com. tr; http: //www. bosch. com. Annual Report for 2005.

(2)The share of each company is calculated by dividing production quantity of its to total production

(4) Annual Reports of Vestel http: //www. vestelyatirimciiliskileri. com/

http: //www. vestelyatirimciiliskileri. com/reports/pdf/2006/VestelElektronik2006FR. pdf 
In this rapidly growing market, there were only two producers for a long time until the third company started to production in 2000. Arçelik is the first one, the other one is the Bosch -Siemens-Profilo. Arçelik is the leader company and B-S-P has been following Arcelik. Arçelik produced the 45 per cent of all refrigerator production in Turkey, in 2002 where the total refrigerator sales by the same companies were 1. 514 million units. Although its market share was 60 per cent in 1996, it decreased to 48 per cent in 2002. There are important influences causing reduction in the market share of Arçelik. Although, import may be evaluated as one of the important factor, the investment carried out by Vestel with high production capacity may also be one the other important reason

\section{4-The Effect of the Customs Union to the Home Appliance Industry}

Table 4. 1: The Customs Duties and Import Tax for Home Appliance Products

\begin{tabular}{|c|c|c|c|c|}
\hline Yens: & Refrigerator & Waxhing Machine & Dish Washer & Vecuum Cleaner \\
\hline $1985(1)$ & $40 \%+150$ \%/unit & $25 \%+100 \$$ /Units & $25 \%+100 \$$ /mit & $40 \%+1$ S umit \\
\hline $1992(2)$ & $\begin{array}{l}9 \% \text { for the EU } \\
20 \% \text { for non-EU } \\
+92 \$ \text { Units- } 46 \text { \$ units }\end{array}$ & $\begin{array}{l}6.5 \% \text { for the EU } \\
15 \% \text { for non-EU } \\
+16 \% \text { of CIF }\end{array}$ & $\begin{array}{l}2 \% \text { for the EU } \\
5 \% \text { for non-EU } \\
155 \$ \text { inits }\end{array}$ & $\begin{array}{l}8 \% \text { for the EU } \\
18 \% \text { for non-EU } \\
20 \$ \text { units }\end{array}$ \\
\hline 1993(3) & $\begin{array}{l}6 \% \text { for the EU } \\
14 \% \text { for non-EU } \\
35 \$ \text { units- } 45 \% \text { units }\end{array}$ & $\begin{array}{l}6 \% \text { for the EU } \\
15 \% \text { for non-EU } \\
+35 \$ \text {. Unit }\end{array}$ & $\begin{array}{l}1 \% \text { for the EU } \\
3.5 \% \text { for non-EU } \\
+17 \% \text { of CIF value }\end{array}$ & $\begin{array}{l}6 \% \text { for the EU } \\
132 \% \text { for non EU } \\
20 \$ \text { /unts }\end{array}$ \\
\hline $1994(4)$ & $\begin{array}{l}3 \% \text { for the EU } \\
9.4 \% \text { for non-EU } \\
355 / \text { units }-45 \$ \text { units }\end{array}$ & $\begin{array}{l}3 \% \text { for the EU commies } \\
10.6 \% \text { for non-EU } \\
+35 \$ \text { per unit }\end{array}$ & $\begin{array}{l}1,9 \% \text { for the EU } \\
4,9 \% \text { for non-EU } \\
755 / \text { mits }\end{array}$ & $\begin{array}{l}3 \% \text { for the EU } \\
9.3 \% \text { for non-EU }\end{array}$ \\
\hline $1995(5)$ & $\begin{array}{l}\text { Free of Charge for the } \\
\text { EU } \\
3.8 \% \text { for non-EU }\end{array}$ & Free of Charge for the EU & $\begin{array}{l}\text { Free of Charge for } \\
\text { EU } \\
2.8 \% \text { for EU }\end{array}$ & $\begin{array}{l}\text { Free of Charge for } \\
\text { the EU } \\
33 \% \text { for non EU }\end{array}$ \\
\hline
\end{tabular}

(1) Türkiye Cumhuriyeti Resmi Gazetesi dated on 12/31/1985, issue 18970 pp: $98,102,124$

(2) Türkiye Cumhuriyeti Resmi Gazetesi dated on 12/31/ 1992, issue 21452 pp: 65, 194,

(3) Türkiye Cumhuriyeti Resmi Gazetesi dated on 12/31/1993, issue 21805 pp: 219

(4) Türkiye Cumhuriyeti Resmi Gazetesi dated on 12/31/1994, issue 22158 pp: 238, 249

(5) Türkiye Cumhuriyeti Resmi Gazetesi dated on 12/31/1995, issue 22510 pp: 194, 620

The tariff rate and the other customs duties applied to the products imported from the EU decreased gradually from 1985 to 1996. Although, 40 per cent tariff rates and 150\$/units customs duties were applied for refrigerator in 1985, only 3 per cent for the products imported from the EU in 1995. Similarly, the tariff rate applied to washing machine and dish 
washer imported from the EU was 25 per cent and the customs duties was $100 \$$ units per unit in 1985 .

The tariff rate applied to the washing maschine imported from EU reduced to 3 per cent for the EU countries and 10.6 per cent for non-EU + $35 \$$ per unit. The import tax applied to vacuum cleaner was 40 per cent and $1 \$$ per unit in 1985 .

\section{1. Export of Four Major Products}

Table 4. 2: Turkey's Export in Home Appliances Industry

\begin{tabular}{|l|c|c|c|c|c|c|c|c|c|c|c|}
\hline Years & 1996 & 1997 & 1998 & 1999 & 2000 & 2001 & 2002 & 2003 & 2004 & 2005 & 2006 \\
\hline $\begin{array}{l}\text { Million } \\
\text { S USA }\end{array}$ & 318 & 377 & 400 & 456 & 472 & 574 & 855 & 1292 & 1652 & 1947 & 2406 \\
\hline
\end{tabular}

Source: For the period between 2002-2006 (Esen, 2007: 4)

http: //www. igeme. gov. tr/bey 2804 azesy.

For the period between 2000-2001 (Yüzal, 2006) )http: // www. igeme. gov. tr/beyazesy. For the period between 2000-1999 (Yüzal, 2005) )http: // www. igeme. gov. tr/beyazesy. For the period between 1999-1996 www. igeme. gov. tr

Exports of the Turkish home appliances sector have been increasing steadily. Refrigerator, washing machine, ovens-cooker and dishwasher are the leading export products of the sector. The large part of home appliance products were exported and the large parts of export has been made to the EU countries. Exports of home appliances were only $\$ 25$ million in 1990 and it increased to $\$ 475$ million in 2000 , to 1947 million USD $\$$ by the year 2005 (İGEME, 2006).

In 1993, 38 per cent, in 199446 per cent, in 199639 per cent, in 2000, 37 per cent, in 2004, 53 per cent, in 200562 per cent of total production were exported. In contrast to the imported products, generally, low quality products have been exported to both The EU and to the other countries at low prices 14 per cent to the United Kingdom, 11 per cent to Spain, 12 per cent to France, 64 per cent of the refrigerator was exported to EU countries, in 2005. Arçelik has the market share of 12 per cent in the refrigerator market of the UK. 
Table 4. 3: Turkey's Exports of Home Appliances By Destination (Million USA \$)

\begin{tabular}{|l|r|r|r|r|r|r|r|r|r|r|r|}
\hline Country & $\mathbf{1 9 9 6}$ & $\mathbf{1 9 9 7}$ & $\mathbf{1 9 9 8}$ & $\mathbf{1 9 9 9}$ & $\mathbf{2 0 0 0}$ & $\mathbf{2 0 0 1}$ & $\mathbf{2 0 0 2}$ & $\mathbf{2 0 0 3}$ & $\mathbf{2 0 0 4}$ & $\mathbf{2 0 0 5}$ & $\mathbf{2 0 0 6}$ \\
\hline U.K. & 34 & 53 & 76 & 78 & 79 & 95 & 144 & 178 & 213 & 214 & 295 \\
\hline Germany & 43 & 61 & 56 & 67 & 59 & 53 & 97 & 144 & 188 & 218 & 239 \\
\hline France & 37 & 36 & 38 & 40 & 42 & 58 & 86 & 116 & 140 & 184 & 241 \\
\hline Spain & 17 & 15 & 17 & 45 & 38 & 39 & 51 & 80 & 119 & 120 & 147 \\
\hline Italy & 16 & 22 & 22 & 29 & 28 & 29 & 41 & 53 & 76 & 101 & 130 \\
\hline Others & 45 & 189 & 183 & 148 & 226 & 78 & 115 & 711 & 916 & 1110 & 1354 \\
\hline TOTAL & $\mathbf{3 1 8}$ & $\mathbf{3 7 7}$ & $\mathbf{4 0 0}$ & $\mathbf{4 5 6}$ & $\mathbf{4 7 2}$ & $\mathbf{5 7 4}$ & $\mathbf{8 5 5}$ & $\mathbf{1 2 9 2}$ & $\mathbf{1 6 5 2}$ & 1947 & $\mathbf{2 4 0 6}$ \\
\hline
\end{tabular}

Source: For the period between 2002-2006 (Esen, 2007: 4) http: //www. igeme. gov. tr/beyazesy.

For the period between 2000-2001 (Yüzal, 2006) ) http: //www. igeme. gov. tr/beyazesy. For the period between 2000-1999 (Yüzal, 2005) ) http: //www. igeme. gov. tr/beyazesy.

For the period between 1998-1996 www. igeme. gov. tr

The main export markets for the home appliance products are the EU countries.

\section{2. Import of Four Major Products}

Turkey's home appliances import also followed an increasing trend with the exception of economic crisis, especially, devaluation periods. In 1997, the volume of total of four leading home appliance products was just \$ USD 526 million, it was \$ USD 765 million in 2005 . The effect of devaluation can be observed in 2001 and 2002 dramatically. The decrease in comparison to previous year was a 49 per cent in 2001 . The reason for such large decrease was devaluation in TL in that year. Decrease in import continued in 2002. It was 12, 7 per cent in comparison to the preceding year. By the recovery in Turkish Economy, the import has also increased from 2002 to 2006.

Table 4. 4: Import of Four Major Home Appliance Products ${ }^{4}$

\begin{tabular}{|l|c|c|c|c|c|c|c|c|c|c|}
\hline Years & 1997 & 1998 & 1999 & 2000 & 2001 & 2002 & 2003 & 2004 & 2005 & 2006 \\
\hline $\begin{array}{l}\text { Million } \\
\text { USAS }\end{array}$ & 526 & 562 & 505 & 589 & 286 & 258 & 389 & 584 & 765 & 916 \\
\hline
\end{tabular}

Source: Esen, 2007: 4

In 1997, Italy was the main country of origin for the import of four products Germany was following Italy. From 1998 to 2000, South Korea was the main country of origin for the home appliance products. From 2003 to 2006 , China became the main country of origin.

${ }^{4}$ These products are refrigerator, washing machine, dish washer and cooking appliances. 
Table 4. 5: Turkey's Imports By Country of Origin / Million USA \$

\begin{tabular}{|l|r|r|r|r|r|r|r|r|r|r|}
\hline Country & 1997 & 1998 & $\mathbf{1 9 9 9}$ & $\mathbf{2 0 0 0}$ & $\mathbf{2 0 0 1}$ & $\mathbf{2 0 0 2}$ & $\mathbf{2 0 0 3}$ & $\mathbf{2 0 0 4}$ & $\mathbf{2 0 0 5}$ & $\mathbf{2 0 0 6}$ \\
\hline China & 24 & 21 & 35 & 72 & 53 & 44 & 95 & 163 & 286 & 327 \\
\hline Germany & 79 & 104 & 74 & 84 & 38 & 41 & 51 & 87 & 109 & 112 \\
\hline Italy & 125 & 109 & 78 & $\mathbf{8 7}$ & 41 & 45 & 62 & 72 & 69 & 85 \\
\hline France & 27 & 49 & 43 & 49 & 25 & 27 & 38 & 62 & 54 & 50 \\
\hline $\begin{array}{l}\text { South } \\
\text { Korea }\end{array}$ & 86 & 106 & 107 & 126 & 43 & 22 & 21 & 23 & 30 & 42 \\
\hline Japan & 44 & 48 & 41 & 36 & 19 & 10 & 7 & 11 & 17 & 22 \\
\hline Thailand & 10 & 16 & 30 & 39 & 13 & 9 & 7 & 12 & 19 & 41 \\
\hline Poland & - & - & - & - & - & - & 4 & 11 & 19 & 28 \\
\hline Others & 129 & 122 & 93 & 91 & 45 & 43 & 85 & 109 & 131 & 210 \\
\hline TOTAL & 526 & 562 & 505 & 590 & 287 & 250 & 363 & 550 & 734 & 917 \\
\hline
\end{tabular}

Source: Türkiye Dış Ticaret Müsteşarlığı, Dış Ticaret Istatistikleri . www. dtm. gov. tr (Turkish Under-secretariat for Foreign Trade, Foreign Trade Statistics)

The reason for this change in the country of origin would be explained by the fact that some of Turkish Producers started to produce in South Korea and China in their own factories in these countries. If we consider that this high volume of import from South Korea and China were provided by Turkish originated products, Italy, Germany, France or any other European Union countries were the main country of origin for this period. The total amounts of import of the four leading home appliance products continued to increase from 1997 until 2001. It decreased to 772 units in 2001 , because of economic crises in Turkish economy. Especially, the import of refrigerator continued to decrease until 2006. The level of import went down beyond the level existed in pre-CU period within this period. Although, the total import value of refrigerator increased to USD $\$ 116$ million, in 1998, it decreased again to 18 in 2002. 
Table 4. 6: Import Volume of Four Major Home Appliance Products in Turkey

\begin{tabular}{|c|c|c|c|c|c|c|c|c|c|}
\hline Years & \multicolumn{2}{|c|}{ Refrigerator } & \multicolumn{2}{|c|}{ Washing Machine } & \multicolumn{2}{|c|}{ Dish Washer } & \multicolumn{2}{|c|}{ Vacuum Cleaner } & Total \\
\hline & $\begin{array}{c}\mathbf{Q} \\
\text { (1) }\end{array}$ & $\begin{array}{c}V \\
(2)\end{array}$ & $\begin{array}{c}\mathbf{Q} \\
\text { (1) }\end{array}$ & $\begin{array}{c}V \\
(2)\end{array}$ & $\begin{array}{c}\mathbf{Q} \\
\text { (1) }\end{array}$ & $\begin{array}{c} \\
(2)\end{array}$ & $\begin{array}{c}\mathbf{Q} \\
(\mathbf{1})\end{array}$ & $\begin{array}{c}V \\
(2)\end{array}$ & $\begin{array}{c}V \\
(2)\end{array}$ \\
\hline 1990 & 21 & $\frac{1-2}{6}$ & 41 & 14 & 57 & 23 & 16 & 1 & 45 \\
\hline 1995 & 68 & 29 & 76 & 22 & 21 & 77 & 152 & 23 & 82 \\
\hline 1996 & 133 & 59 & 233 & 65 & 80 & 25 & 350 & 45 & 197 \\
\hline 1997 & 147 & 90 & 284 & 99 & 112 & 40 & 609 & 65 & 298 \\
\hline 1998 & 186 & 116 & 317 & 77 & 211 & 55 & 449 & 44 & 304 \\
\hline 1999 & 323 & 84 & 231 & 49 & 183 & 45 & 505 & 37 & 223 \\
\hline $2000^{*}$ & 214 & 75 & 359 & 75 & 220 & 49 & 573 & 37 & 251 \\
\hline $2001^{*}$ & 187 & 31 & 173 & 33 & 105 & 23 & 307 & 17 & 107 \\
\hline $2002^{* *}$ & 51 & 18 & 159 & 35 & 99 & 22 & 300 & 9 & 85 \\
\hline $2003 * *$ & 41 & 19 & 191 & 38 & 102 & 28 & 533 & 21 & 106 \\
\hline $2004 * *$ & 44 & 23 & 187 & 42 & 177 & 49 & 854 & 37 & 151 \\
\hline $2005^{* *}$ & 63 & 26 & 113 & 83 & 200 & 55 & 1433 & 65 & 229 \\
\hline
\end{tabular}

Q(1) : Quantity (000 Units ), V(2): Value (Million USD \$)

Sources for Quantity (000 Units ): Türkiye İstatistik Kurumu, Data Procurement Service Sources for Value (USD \$):

* Yuzal, 2006, http: //www. igeme. gov. tr/english/sectors/index. $\mathrm{cfm}$ ? sec=sectors

** Esen, 2007, http: //www. igeme. gov. tr/english/sectors/index. cfm?sec=sectors

\section{3. The Impact of Increasing Import on Refrigerator Market}

Refrigerator import has been fluctuated depending on foreign exchange value. The increase in 1996 was depending on the reason that customs duties for the imports from the EU Member States removed and import got cheaper 7 per cent in this year. The refrigerator import only increased 32 per cent in 1997, 74 per cent in 1998. Nevertheless, it reduced by 34 per cent in 1999 and 13 per cent in 2000 . Besides, the factors relating to general economic conditions, introduction of new products by Vestel's refrigerator facilities. Following technical developments in industry, the import reduced 55 per cent in 2001 . Total demand has been procured via import as an 8 per cent in 1996, 13 per cent in 1997, 23 per cent in 1998, 17 per cent in 1999; 13 per cent in 2000; 6 per cent in 2001; 2 per cent in 2002, per cent 3 in 2003. 
Graph 4. 1



Source: Türkiye Beyaz Eşya Sanayicileri Derneği

Although, it was expected that there should be significant decrease in refrigerator prices depending on the $\mathrm{CU}$, this has not been observed in the period between 1996 and 2002. Even, there is almost no change in price level. However, if the price emerged in 1990 is compared to the price emerged in 2002, 2 only per cent price change can be observed. The price of imported product is almost three times higher than the price of exported product. So, this can be interpreted as the imported products are more luxury model of refrigerators. In the early period between 1998- 2001, Vestel introduced product which it imported by itself. Therefore, prices were down. However, it started to rise again by 2002

Depending on large fluctuations in foreign exchange, the dometic prices in USA $\$$ also fluctuates largely on yearly basis. However, in Türk Lirası (TL) domestic prices changes paralel to inflation

Demir calculated the concentration ratios for home appliance sector for the year 1997. CR4, CR8 and HR Index demonstrated high concentration in the appliance sector. CR4 was 62, 93. CR8 was 82. H- Index was 0, 1208 (Demir, 2001). Since these ratios have demonstrated that the four leading firm are dominating the home appliance sector 
Table 4. 7: Refrigerator Prices in Turkey (USD \$)*

\begin{tabular}{|c|c|c|c|c|c|c|}
\hline Years & $\begin{array}{c}\text { Export } \\
\text { Price } \\
(1)\end{array}$ & $\begin{array}{c}\text { Change in } \\
\text { Export Price } \\
\%\end{array}$ & $\begin{array}{c}\text { Import } \\
\text { Price } \\
(2)\end{array}$ & $\begin{array}{c}\text { Change in } \\
\text { Import Price } \\
\%\end{array}$ & $\begin{array}{c}\text { Domestic } \\
\text { Price } \\
(3)\end{array}$ & $\begin{array}{c}\text { Change in } \\
\text { Domestic } \\
\text { Price } \%\end{array}$ \\
\hline 1990 & 177 & 10 & 320 & 35 & 501 & \\
\hline 1995 & 157 & 4 & 451 & 1 & 512 & 27 \\
\hline 1996 & 195 & 24 & 437 & -3 & 522 & 2 \\
\hline 1997 & 200 & 3 & 474 & 8 & 497 & -5 \\
\hline 1998 & 204 & 2 & 359 & -24 & 499 & 0 \\
\hline 1999 & 236 & 16 & 385 & 7 & 491 & -2 \\
\hline 2000 & 174 & -26 & 382 & -1 & 534 & 9 \\
\hline 2001 & 166 & -5 & 360 & -6 & 444 & -17 \\
\hline 2002 & 182 & 10 & 392 & 31 & 455 & -15 \\
\hline 2003 & 164 & 10 & 430 & 9,6 & 535 & 17,5 \\
\hline 2004 & 181 & 9 & 440 & 2,3 & 400 & 25,2 \\
\hline 2005 & 187 & 3 & 490 & 11,3 & 646 & 61,5 \\
\hline
\end{tabular}

(1) The average prices calculated by division of export income over export quantity

(2) The average prices calculated by division of the import expenditure over import quantity.

(3) The data obtained from TÜIK, Price Statistics, Consumer Price Indexes and converted to $\$$ USD by using Foreign Exchange Value declared by TCMB.

Source: TÜIK, Price Statistics, Monthly Database; Foreign Trade Statistics from Information Department. http: //tuikrapor. tuik gov. tr/reports/ rwservlet?fiyatdb2\& report=tufe_fiyat_2003.

RDF \&desformat $=h t m i \& p \_b a z=2003 \& p \_t u r=0 \& p \_$yill $=2006 \& p \_$yil $2=2006 \& p \_$ay $1=1 \& p \_a$ y $2=2 \& p \_a y 3=3 \& p \_a y 4=4 \& p \_a y 5=5 \& p \_a y 6=6 \& p \_$ay $7=7 \& p \_a y 8=8 \& p \_$ay $9=9 \& p \_$ay $10=10$ $\& p \_a y l \vec{l}=11 \&$ p_ay $12=12 \&$ yer $l=999 \& p \_$kod $1=053111$

* Domestic prices were obtained from TÜIK. There are two categories of prices in the data; one is for the refrigerator with one door; the other one is for the refrigerator with two doors. The domestic price used in this analysis shown in table is the average of these two types.

Table 4. 8: 4 Firm Concentration Ratios in Manufacturing for the Home Appliance Sector*

\begin{tabular}{|l|l|l|l|}
\hline Years & 1985 & 1987 & 1989 \\
\hline Concentration Ratíos & 50.6 & 51.1 & 51.0 \\
\hline
\end{tabular}

Source : Tiktık, 1997: 24

* Home Appliance Sector is classified as Electrical Machinery Group

Especially, the first firm controlled the $60 \%$ of the whole market in 1997, although, this ratio decreased to $54 \%$ by the year 2002 . Therefore, it is important to analyse these two leading firm's profit. What it can be observed that the market share of domestic producer decreased. In addition to this, Demir also calculated profit cost margin as 27.6 per cent, import penetration ratio as 9.9 per cent in electrical appliances. 
Table 4. 9: Net Profit Margin \%

\begin{tabular}{|c|c|c|c|c|}
\hline Years & $\begin{array}{c}\text { Whirlpool } \\
(\mathbf{1})\end{array}$ & $\begin{array}{c}\text { Arcelik } \\
(\mathbf{2})\end{array}$ & $\begin{array}{c}\text { BSH Profilo } \\
(\mathbf{3})\end{array}$ & $\begin{array}{c}\text { Vestel } \\
(4)\end{array}$ \\
\hline 1991 & 2.1 & 9 & & N. A. \\
\hline 1992 & 2.5 & 8 & 2 & 0.7 \\
\hline 1993 & 3.5 & 8 & 4 & 1.7 \\
\hline 1994 & 1.8 & 4 & 1 & 0.16 \\
\hline 1995 & 2.5 & 6 & 4 & 0.9 \\
\hline 1996 & 1.8 & 10 & 4 & 8.5 \\
\hline 1997 & -0.5 & 11 & 4 & 9.5 \\
\hline 1998 & 3.0 & 9 & 5 & 6.5 \\
\hline 1999 & 3.3 & 11 & 5 & 7.1 \\
\hline 2000 & 3.6 & 7 & 5 & 7.2 \\
\hline 2001 & 0.3 & -14.9 & -2 & 2.2 \\
\hline 2002 & 2.4 & 2.3 & 2 & 1.8 \\
\hline 2003 & 3.4 & 4.5 & 4.4 & 2 \\
\hline 2004 & 3.0 & 5.9 & 4.5 & 2 \\
\hline 2005 & 2.9 & 6.1 & 6.3 & 2 \\
\hline 2006 & 2.3 & 4.7 & 7.1 & 1.6 \\
\hline
\end{tabular}

Source: Companies and Istanbul Menkul Kiymetler Borsası

(1) http: //media. corporate-ir. net/media_files/nys/whr/reports/whr_980101_200_120. pdf http: //media. corporate-ir. net/media_files/irol/97/97140/WHR_A $\bar{R} 05 /$ WHR_ $\overline{2005 A R}$. pdf http: //media. corporate-ir. net/media_files/irol/97/97140/2006ar/whr_section5. pdf (2)for the year between 1992-1998: http: //www. imkb. gov. tr/bilanco/mtablo92-97. htm for the year between 1999-2004: http: //www. imkb. gov. tr/bilanco/mtablodonem. htm for the year 2005: http: //www. arcelikas. com. tr/NR/rdonlyres/8AAADFDA-E8F6-A996919E091ECBBE/17139/ARCELIKFR05. pdf

for the year $2006: \mathrm{http}: / / \mathrm{www}$, arcelikas. com. tr/NR/rdonlyres/9D2E387C-5462-482D92CD- 4C581D9D23A/17140/ARCELIKFR06. pdf

(3) for the year between 1992-1998: http: //www. imkb. gov. tr/bilanco/mtablo92-97. htm for $1999 \mathrm{http}: / / \mathrm{www}$. imkb. gov. tr/bilanco/1999/12/tbshev. zip for $2000 \mathrm{http}: / / \mathrm{www}$. imkb. gov. tr/bilanco/2000/12/tbshev. zip for $2001 \mathrm{http}: / / \mathrm{www}$. imkb. gov. tr/bilanco/2001/12/tbshev. zip for $2002 \mathrm{http}: / / \mathrm{www}$. imkb. gov. tr/bilanco/2002/12/tbshev. zip for 2003 http: //www. bsh. com. tr/assets/pressroom/pi_assetname_13.pdf for $2004 \mathrm{http}$ : //www. bsh. com. tr/assets/pressroom/pi_assetname_15. pdf for $2005 \mathrm{http}: / / \mathrm{www}$. bsh. com. tr/assets/pressroom/pi_assetname_17. pdf for 2006 http: //www. bsh. com. tr/assets/pressroom/_new_pi_assetname_200751014 829265179. pdf

(4) for the year between 1992-1998 : http: //www. imkb. gov. tr/bilanco/mtablo92-97. htm for the year between 1999-2006: http: //www. imkb. gov. tr/bilanco/mtablodonem. htm http: //www. vestelyatirimciiliskileri. com/reports/pdf/2006/VestelElektronik2006FR. pdf 
In the research, the net profit margin was calculated by net profit of firms over net sales for the period between 1991 and 2002. It was observed that net profit margin of domestic firms was larger than the net profit margin of international firms. Also, the net profit margin for the firms did not decrease after the completion of the $\mathrm{CU}$. The comparison of consolidate sales of leading world wide multinational companies and domestic firms are given in the following table. Arçelik has been following the highest net profit margin (Net profit/Sales) since 1991, before and after the CU. Even the local value of BSH has been also higher than the ratio of Whirlpool Incorporation. The following table shows the tendency of net profit margin of three leading homew appliance companies in Turkey and Whirpool which is an international company and not producing in Turkey.

\section{5 -Conclusion}

The aim of this study was to evaluate the impact of the Customs Union on Home Appliance Manufacturing Industry in Turkey. The basic idea behind the Customs Union is to utilise the benefits of free trade among the trading parties. Depending on the challenges in theories, the policy arguments have also been changed. Especially, development in industrial economics and the arguments for the structure conduct performance paradigm and game theory put forward the policies which can also be effective in international trade. While trade liberalization would remove trade barriers and make markets more competitive, changes in the market structure from concentrated markets to competitive markets would also change the conduct of the companies, companies would start to behave more competitively and reduce prices and the extraordinary profits. The selective use of trade barriers and industry subsibidies in order to capture the profits handled by foreign firms is only one of these policies. The effective trade and industry policies, especially import policies would discipline the markets which are highly concentrated. In these markets, import disciplines the extraordinary profits of the firms. Home appliance industry in Turkey was one of these highly concentrated industries. The removal of trade barriers also made the home appliance industry more competitive. The market share of Arcelik consdireably. The volume of import increased, the net profit margin for two producers in the industry decreased. Although, the net profit of Whirlpool, a leading international company in home appliance industry was lower than Arcelik's net profit margin, in Arcelik's net profit decreased significantly.

Finally, the study concludes that trade liberalization in Turkey enjoyed a serious improvement since 1980 , its speed has been accelerated 
tremendously through the Customs Union. The home appiance industry also enjoyed serious development in production, export and import. The main countries of origin for import and the main countries of destionation for export have been the European Union Countries. However, we still have high profit cost margin in home appliance sector.

\section{References:}

Akkoyunlu, Arzu and Mihcı, Sevinç and Hakan Arslan. (2006). 'The Customs Union with EU and Its Impact on Turkey's Economic Growth', $8^{\text {th }}$ ETSG Annual Conference, Vienna. Retrieved: June 14, 2007. from: http://www.etsg.org/ETSG2006.Papers/akkoyunlu/pdf.

"Arçelik Türkiye ye dar gelmeye başladı." (June 24, 2005). Akşam Daily News. Retrieved: March 3, 2006 from: http: //www. aksam. com. tr/arsiv/ aksam/2005/06/24/ekonomi/ekonomi/2. html

Annual Report of Arcelik. 2002. Arçelik. Retrieved: May 14, 2005 from: http://www.arcelik.com.tr.

Annual Report of Arcelik. 2004. Arçelik. Retrieved: May 14, 2005 from: http://www.arcelik.com.tr.

Annual Report of Arcelik. 2005. Arcelik. Retrieved: May 14, 2005 from: http://www.arcelik.com.tr

Presentation for Arçelik. 2007. Arçelik. Retrieved: September 7, 2007 from: http://www.arcelikas.com.tr/Cultures/trTR/Medyalliskileri/KurumsalSun us/?MENUID=3

Annual Report for 2006. Bosch Siemens Profilo. B/S/H. Retrieved: May 19, 2007 from: http://www.bshp.com._new_pi_assetname_2007510148296 5179.

Annual Report for Bosch Siemens Profilo. 2005. Retrieved: May 19, 2007 from http://www.bshp.com.

Annual Report of Vestel for 2006. Retrieved: May 14, 2007 from http://www.vestel.com.tr

Dixit, Avinash. (1986). 'Trade Policy: An Agenda for Research'. Paul Krugman (ed.), Strategic Trade Policy and the New International Economics. MIT Press. 
Esen, Bora. (2007). Beyaz Eşya Sanayisi 2007, İhracatı Geliştirme Merkezi. Ankara. Retrieved: September 9, 2007 from http://www.igeme.org.tr/ Arastirmalar/ulke_sek/sektor.cfm?sec=ara

Eroğlu, Omer and Gokhan. Ç, Özdamar (2006). "Competitiveness of The Turkish Manufacturing Industry and A Study On The Household Appliances Industry" Akdeniz I. I. B. F. Dergisi. (11) Retrieved September 8, 2007 from: http://www.akdeniz.edu.tr/iibf/yeni/genel /dergi/sayi11/08eroglu.pdf.

Baghwati, J. (1987). 'An Introduction to Part IV: Quotas and Voluntary Export Restraints (VER)s'. Jagdish Baghwati (ed.), International Trade, Cambridge: MIT Press.

Hatay, Levent And Tuncer, Timur. (2003). "Vestel Durable Goods. Retrieved: May 12, 2007 from http://www.vestel.com.tr/NR/rdon lyres/E4F95A36-34AA-478-AE603886A7f73533/8255/kocGSB_vestel. pdf.

Istanbul Menkul Kıymetler Borsası, Istanbul Stock Exchange, Financial Statements (1992-1997), Stock: ARCELK-ARCELIK Year: 1992-1997; Period for 06-12. 17 March 2003.

Istanbul Menkul Kiymetler Borsasi, Istanbul Stock Exchange, Financial Statements. Retrieved: March 5, 2004. http://www.imkb.gov.tr/bilanco /mtablo9297.htm.DIYX900S/tarclk[1] Date modified: 6/16/199810: 29AM.

Istanbul Menkul Kiymetler Borsas1, Istanbul Stock Exchange, Financial Statements. Retrieved: April 8, 2005 from http://www.imkb.gov.tr/ bilanco/gecicivergi200412aylik.htm./AXANFQVZ./tgv20042arclk(1) issued on 15. 02. 2005.

Istanbul Menkul Kiymetler Borsası, (Istanbul Stock Exchange Presidency) (September 21, 1993). Declaration about Arcelik.

Istanbul Menkul Kıymetler Borsası, (Istanbul Stock Exchange Presidency) (January 1, 1995). Declaration about Arcelik

Istanbul Menkul Kiymetler Borsası, (Stock Exchange Presidency. (March 03, 1995). Declaration about Arcelik

Istanbul Menkul Kiymetler Borsası (Istanbul Stock Exchange Presidency. (June 03, 1994). Declaration about Arcelik I 
Istanbul Menkul Kiymetler Borsası (Istanbul Stock Exchange (2005). Yearly Financial Statements Given as An Attachment to Declaration to Tax Office.

Istanbul Menkul Kiymetler Borsası (Istanbul Stock Exchange (2005). Yearly Financial Statements Given as An Attachment to Declaration to Tax Office for Arçelik. Retrieved: May 15, 2006 from http://www.imkb.gov.tr/bilanco/gecicivergi200512aylik.htm/tgv200512a rcelik(1) issued on. 02/14/. 2006. 6: 11

İhracatı Geliştirme Merkezi, (1985). Dayanıklı Tüketim Malları İhracat Pazar Araştırması. Ankara.

Ihracatı Geliştirme Merkezi, (1973). Türkiye'de Buzdolabı Endüstrisi ve İhraç Olanaklan. (The Refrigerator Industry in Turkey and Opportunities for Export) Publication. No. 38. Ankara.

Istanbul Menkul Kiymetler Borsası. ( Istanbul Stock Exchange. ) End notes of Balance Sheet of Arçelik For the Period of December 32, 1997 and December 31, 1998. Retrieved: February 03, 1999 from http://www.imkb.gov.tr/bilanco/mtablodonem.htm.

Istanbul Menkul Kiymetler Borsası (2005). Yearly Financial Statements Given as an Attachment to Declaration to tax office for Bosch Profilo. Retrieved: May 15, 2006 from http://www.imkb.gov.tr/bilanco/ gecicivergi200412aylik.htm/tgv200112bspro(1) íssued on 02/14/. 2005.

Istanbul Menkul Kiymetler Borsası (2005). Yearly Financial Statements Given as an Attachment to Declaration to tax office for BoschProfilo. Retrieved: May 15, 2006 from. http://www.imkb.gov.tr/bilanco/gecici vergi200412aylik.htm/tgv200112bspro(1) issued on 02/14/. 2005.

Istanbul Menkul Kıymetler Borsası (2006). Yearly Financial Statements Given as an Attachment to Declaration to tax office for Bosch Profilo. Retrieved: May 15, 2006 from http://www.imkb.gov.tr/bilanco/ gecicivergi200512aylik.htm/tgv200112bspro(1) issued on 02/14/.2006.

Istanbul Menkul Kıymetler Borsası (2005). Yearly Financial Statements Given as an Attachment to Declaration to tax office for Vestel. Retrieved: May 15, 2006 from http:/www.imkb.gov.tr/bilanco/ gecicivergi200412aylik.htm/tgv200412vestl.zip issued on 02/15/2005. 
Istanbul Stock Exchange. (2006). Yearly Financial Statements Given as an attachment to declaration to tax office for Vestel. Retrieved: February 15, 2006. from http://www.imkb.gov.tr/bilanco/gecicivergi200512aylik. $\mathrm{htm} / \operatorname{tgv} 200512$ vestl.zip(1) issued on 02/15/2005.

Katırcioğlu, E. , N. Engin and C. Akçay(1995), " The Impact of Trade Liberalization on the Turkish Manufacturing Industry: An Empirical Assessment", Policies for Competition and Competitiveness, The Case of Industry In Turkey. ed. by Refik Erzan. United Nations Industrial Development Organization, Vienna.

Koç Holding. Activity Report for Koc Holding Corporation. 2001

Krueger, Ann and Tuncer, Baran (1982). "An Empirical Test of Infant Industry Argument", The American Economic Review, Vol. 72, No. 5. pp. 1141-1152Retrieved: May 15, 2003 from http://links.jstor. org/sici?sici $=0002-282(198212) 72 \% 3$ A5\%3C1 142\%3AAETOTI\%3E2.

$0 . \mathrm{CO} \% 3 \mathrm{~B} 2-5$

Levinsohn, John (1993). "Testing the Imports As Market Discipline Hypothesis" Journal of International Economics, 35.

Neyaptı, Bilin and Taşkın, Fatma and Murat Üngör. (2004). 'Has European Customs Union Agreement Really Affected Turkey's Trade?' Applied Economics (39) Retrieved: June 14, 2007 from http://wwww.ecomod.net/ conferences/ecomod2003_papers/Neyapti.pdf.

Özcan, Kıvilcım and Voyvoda, Ebru and Erinç Yeldan. (2001). 'On the Pattern of Trade Liberalization, Oligopolistic Concentration and Profitability: Reflection from Post-1980 Turkish Manufacturing'. Bilkent University, Department of Economics. Retrieved on November 15, 2004 from http://ideas.repec.org/bil/ bilpap/012.html.

Özkale, Lerzan and Karaman, Fatma (2006). 'Static Effects of the EUTurkey, Customs Union', International Economics and Foreign Trade Policies (1). ITU. Retrieved on: May 14, 2007 from www.etsg.org/ ETSG2006/papers/KARAMAN.pdf.

PEG Profilo Electrical Equiment Incorporations(1995). Activity Report for Profilo Electrical Equipment Industry Incorporations.

Rekabet Kurulu, (Competition Board) (March 09, 2003). Decision on " The claim about Arçelik for abusing the dominant position in white goods appliance industry against white goods suppliers". Retrieved: November 2, 2007 from http://www.rekabet.gov.tr/pdf/00-39-436-242.pdf. 
Saatçi, Mustafa and Aslan, Alper. (2007). “Türk İmalat Sanayinde İthalatın Piyasayı Disipline Edici Etme Hipotezinin Testi: Panel Veri Yaklaşımı”, Erciyes Universitesi Iktisadi ve Idari Bilimler Fakültesi Dergisi (29). Retrieved: August 30, 2007 from http://iibf.erciyes.edu.tr/dergi/sayi29 /msaatci.pdf. (On the publication process.)

Seymen, Dilek and Utku Utkulu, (2006). 'Trade and Competitiveness Between Turkey and the EU: Times Series Evidence,' Turkish Economic Association Discussion Paper, 8 Ankara. Retrieved: May 15, 2007 from http://www.tek.org.tr/dosyalar/D.SEYMEN-U.UTKULU.pdf.

Togan, Subidey (1998). Foreign Trade Liberalization in Turkey during the 1980s. England: Adhgate Publishing Limited.

Togan, Subidey and Nebioğlu, Hüsamettin and Saddettin Doğan. (2005). 'Integration and The Manufacturing Industry'. Bernard and Hoekman and Subidey Togan. (eds.), Turkey: Economic Reform and Accession to the European Union. The International bank for Reconstruction and Development.

T1ktık, Ahmet (1997). Trade Liberalization Under Imperfect Competition A CGE Analysis on Turkey. Capital Markets Board of Turkey. Publication No. 97.

Türkiye Cumhuriyeti Resmi Gazetesi. (The Official Journal) dated on 12/31/1985, issue 18970 pp 98, 102, 124

Türkiye Cumhuriyeti Resmi Gazetesi. (The Official Journal) dated on $12 / 31 / 1992$, issue $21452 \mathrm{pp} 65,194$,

Türkiye Cumhuriyeti Resmi Gazetesi(The Official Journal) dated on 12/ 31/1993, issue 21805 pp 219

Türkiye Cumhuriyeti Resmi Gazetesi. (The Official Journal) dated on 12/ $31 / 1994$, issue 22158 pp 238, 249

Türkiye Cumhuriyeti Resmi Gazetesi The Official Journal Dated on 12/31, 19951995 issue 22510 pp 194, 620

Türkiye Cumhuriyeti Merkez Bankası (June 2002). "The Impact of Globalization On The Turkish Economy" TCMB. ISBN: 975-7589-72-1, Ankara. Retrieved on: November 14, 2004 from http://www.tcmb.gov.tr.

Turkish Manufacturing Industry: A Panel Data Analysis" Türkiye Cumhuriyeti Merkez Bankası Research Center. Retrieved on: April 9, 2003 from http://www.tcmb.gov.tr/research/discus/dpaper37.pdf. 
Yalçın, Cihan. (2000). "Price, Cost Margins and Trade Liberalization in Turkish Manufacturing Industry: A Panel Data Analysis" Türkiye Cumhuriyeti Merkez Bankası Research Center. Retrieved on: April 9, 2003 from http://www.tcmb.gov.tr/research/discus/dpaper37.pdf.

Yüzal, Sinan. (2006). Beyaz Eşya Sanayisi 2006, Report on White Good Industry 2006, İGEME. Ankara. Retrieved on: September 8, 2007 from http://www.igeme.org.tr/Arastirmalar/ulke_sek/sektor.cfm?sec=ara.

Yüzal, Sinan. (2005). Report on White Good Industry 2005, İhracatı Geliştirme Merkezi. Ankara. Retrieved on: November 14, 2006 from http://www.igeme.org.tr/Arastirmalar/ulke_sek/sektor.cfm?sec=ara. 